\title{
СЛОВОТВОРЧА ПРОДУКТИВНІСТЬ ДІЕСЛІВ ДИНАМІЧНОЇ ПРОСТОРОВОЇ ЛОКАЛІЗОВАНОСТІ 3 ПРЕФІКСОМ ВИ- В УКРАЇНСЬКІЙ МОВІ
}

Сегін Л. В. Словотворча продуктивність дієслів динамічної просторової локалізованості з префіксом ви- в українській мові.

У статті проаналізовано словотворчу спроможність дієслів динамічної просторової локалізованості 3 префіксом ви-. Установлено структуру типової словотвірної парадигми досліджуваних твірних, виявлено типологію словотвірних значень, реалізованих похідними, з'ясовано кількісну наповнюваність кожного структурного блоку і словотвірного значення.

Ключові слова: префіксальне дієслово, типова словотвірна парадигма, словотвірне значення, дериваційний потенціал, похідне слово.

Сегин Л. В. Словообразовательная производительность глаголов динамической пространственной локализуемости с префиксом вbl- в украинском языке.

В статье анализируется словообразовательный потенциал глаголов динамической пространственной локализации 3 приставкой ви-. Устанавливается структура типовой словообразовательной парадигмы исследуемых производящих, выявляется типология словообразовательных значений, реализируемых производными, выяснена количественная наполняемость каждого структурного блока и словообразовательного значения.

Ключевые слова: префиксальный глагол, типовая словообразовательная парадигма, словообразовательное значение, деривационный потенциал, производное слово.

Segin L. V. Performance verb derivation of dynamic spatial lokalizovanosti prefixed with you-, in the Ukrainian language.

The article is devoted to the analysis of word-formative ability of the verbs of dynamic dimensional locality withe the prefix ви-. The structure of the typical wordformative paradigm of the analized formatives is established, as well as the quantitative fullness of enery structural block and word-formative meaning is determined.

Key words: prefixal verb, typical word-formative paradigm, word-formative meaning, derivative potential, derivative.

\section{Словотвірна система сучасної української мови незмінно} привертає увагу дослідників. Вона неодноразово ставала предметом дериваційних досліджень. Не $є$ винятком і дієслівна підсистема словотвору. У таких роботах ключова роль у систематизації, інтерпретації і класифікації дериватів відводиться словотворчому форманту. Сучасні дослідження зі словотвору спрямовані на виявлення й опис дериваційної спроможності класів слів різних частин мови. Цей підхід у лінгвістичній літературі отримав назву 
основоцентричного i передбачає встановлення специфічної комплексної одиниці класифікації й опису дериваційної системи. На думку дериватологів, такою одиницею є словотвірна парадигма (СП) $[7 ; 4 ; 3]$. Термін «словотвірна парадигма» тлумачиться суперечливо й багатозначно. Найбільш детально СП була охарактеризована російським мовознавцем О.А. Земською, яка визначає СП як сукупність похідних, що мотивуються однією твірною основою і перебувають на одному ступені творення [7, с. 71].

На сьогодні в україністиці вже є окремі праці, присвячені опису дериваційного потенціалу різних класів твірних на рівні СП, зокрема прикметників [4], певних груп іменників [3; 11], дієслів [6;12; 14].

Дієслова ДПЛ 3 префіксом ви- ще не були предметом спеціального лінгвістичного аналізу в українській мові.

Мета статті - описати структурно-семантичну типологію СП дієслів ДПЛ з префіксом ви- в українській мові.

Поставлена мета передбачає розв'язання таких завдань:

1) визначити структурну типологію досліджуваних девербативів;

2) установити континуум словотвірних значень, реалізованих похідними від префіксальних дієслів;

3) з'ясувати кількісну наповнюваність кожного структурного блоку, словотвірного значення;

Матеріалом для дослідження послужили 176 девербативів української мови від 85 твірних дієслів, отриманих методом суцільної вибірки з найавторитетніших джерел (СУМ, СУМГ, ВТССУМ).

Як відомо, дериваційні можливості твірного репрезентує СП. Дериватологи констатують, що СП має двоїстий характер, тобто $є$ одиницею плану змісту й плану вираження. Зважаючи на двоплановість конкретної СП, та, як слушно зауважують дослідники, щоб відмежуватися від «примх лексики» у словотворі й простежити закономірності в будові СП, було введено поняття типової СП. О. А Земська відзначає, що «типову СП отримуємо, абстрагуючись від конкретних способів вираження тих чи тих дериваційних значень. Типову парадигму формують конкретні парадигми, у яких наявний однаковий набір дериваційних значень» [7, с. 73].

Під час аналізу конкретних СП дієслів ДПЛ з префіксом $в и$ виявлено похідні чотирьох лексико-граматичних класів: іменники, прикметники, дієслова, прислівники. Отже, типова СП досліджуваних префіксальних дієслів ДПЛ має чотиризонну субстантивноад’єктивно-вербально-адвербіальну структуру 313 словотвірних 
значень (С3): «виконавець дії», «опредметнена дія», «місце дії», «об’єкт», «знаряддя дії» - у субстантивній зоні; «ознака об'єкта», «ознака суб'єкта», «призначений для...» - в ад'єктивній зоні; «за допомогою дії, названої дієсловом, перемістити(ся) звідки-небудь кудись усіх чи багатьох», «виконуючи дію, переводити щось із стану об’єкта в стан суб'єкта», «однократність», «у результаті виконання дії 3'являтися, переміщатися на відкрите місце» - у вербальній зоні; «адвербіалізація дії»- в адвербіальній зоні.

Субстантивна зона типової СП аналізованих лексем $\epsilon$ найчисельнішою і нараховує 84 (47,7\%) деривати. Цю зону формують два типи С3: мутаційні та транспозиційні.

Від українських дієслів ДПЛ 3 префіксом ви- регулярно утворюються девербативи nomina actionis. Порівняно 3 іншими похідними, деривати зі С3 «опредметнена дія» є найчисельнішими у структурі словотвірної парадигми дієслів ДПЛ з префіксом ви-. Про це свідчать і спостереження інших дослідників. Зокрема М. П. Лесюк стверджує, що «віддієслівні іменники з мутаційними С3 творяться різними моделями, однак, незважаючи на багатство словотворчих засобів, ... кількість їх порівняно 3 кількістю транспозиційних дериватів набагато менша, що пояснюється меншою регулярністю i продуктивністю мутаційних моделей» $[10$, с. 75]. Загальна кількість вторинних траспозиційних найменувань у субстантивному блоці типової СП досліджуваних базем становить 63 одиниці, що складає 35,7\% від загальної кількості: вивезення, ви́від, виганяння, виїзд1, вилазка, виліт, виношування, вистрибування, вихід, випадання, виповзання, висунення, викидання, вигул, вигонка (спец.), вилізання, вивозка, випередження, витягування, виплигування, виринання, витягання, вибрикування, вибування, виведення, вибуття, вивіз, виводження, виводка, вигнання, виїждження, виїжджування, викочування, винесення, винос, випадення, випадіння, випереджання, випихання, випливання, випровадження, випроваджування, випроводжання, вирушання, вирушення, виряджання, вирядження, вискакування, вискік, виступ, виступець1, висування, вистриби, витаскування, витягання, витягнення, витяжка, вихідчини (розм., мн.), виходеньки (діал., мн.), виштовхування, виштурхування (розм.), випорскування, витягування. 3-поміж похідних цього С3 виокремлюються іменники вискік («жвавий, енергійний стрибок»), виліт («одноразовий політ»), на транспозиційний зміст яких нашаровується додаткова сема однократності, яка, однак, не 
суперечить значенню опредметненої дії [15, с. 70-74]. Наприклад: ...наша розвідка донесла, щзо на самий Йордан відбудеться вивіз у Сакатурі... (Р. Іваничук).

Зазначимо, що С3 «опредметнена дія» відзначається найбільшою глибиною місць у парадигмі 3-поміж усіх аналізованих C3. Залежно від кількості похідних, що мають одне й те саме С3, семантичні позиції поділяють на одночленні і багаточленні, тобто одна й та ж семантична позиція може бути представлена одним дериватом, двома, трьома i т. ін. Двочленні ряди словотвірних синонімів із С3 «опредметнена дія» характерні для 6 СП, тричленні 5, чотиричленні - 1. Ці синоніми перебувають у різних лексикосемантичних i функціонально-стилістичних відношеннях. Спільноосновні деривати або повністю збігаються за своїми особливостями, або можуть мати розбіжності. За своєю семантикою повністю збігаються такі спільнокореневі девербативи із С3 «опредметнена дія»: виведення - виводження, вивезення - вивіз, випередження - випереджання, випровадження - випроводжання, вирушання - вирушення, виряджання - вирядження, витягання витягнення - витягування. Інші синоніми-девербативи мають відмінності в семантичному або функціонально-стилістичному параметрах: виведення - виводка, вивід, виганяння - вигонка (спец.), виїждження - виїзд, вилізання - вилазка, вилізання - вилазка, вискакування - вискік, висування - висунення, вихід - вихідчини (розм.) - виходеньки (діал.). В окремих випадках виявлено як спільне, так і розбіжності: винесення - винос, випадання - випадіння. Найбільш продуктивними, як для префіксальних твірних, в утворенні дериватів iз С3 «опредметнена дія» є такі дієслова ДПЛ: виводити /вивести, виходити, виносити / винести, виганяти / вигонити / вигнати, випроваджувати / випровадити / випроводжати, менш продуктивними - дієслова вивезти / вивозити, виїжджати /виїздити / виїхати, вилазити / вилізати / вилізти, випадати / випасти, випереджати / випереджувати, вирушати / вирушити, виряджати / вирядити, висувати / висовувати / висунути, витягати / витягувати / витягти, інші префіксальні дієслова продукують по одному деривату (вибрикувати, вибувати / вибути, вигулювати / вигуляти, викидати / викинути, викочувати / викотити, вилітати / вилетіти, випихати / випхати, випливати / виплисти / випливти / виплинути, виплигувати / виплигнути, виповзати / виповзти, виринати / виринути, виселяти / виселити, вискакувати / вискочити, вистрибати / вистрибувати / 
вистрибнути, виступити / виступати, витаскувати / витаскати, вичтовха́ти / виштовхувати / ви́штовхати, виштурхувати / вичтурхати).

Отже, із 85 дієслів ДПЛ 3 префіксом ви- від 33 (38,8\%) зафіксовано синтаксичні деривати, при цьому 14 (42,4\%) твірних мотивує більше ніж один девербатив.

Мутаційний тип деривації представлений такими С3: «виконавець дії», «місце дії», «об’єкт», «знаряддя дії».

Як свідчать проведені дослідження [13; 14], дієслова ДПЛ активно продукують деривати із С3 «виконавець дії», оскільки поняття діяльності передбачає поняття діяча [16, с. 72]. Твірними для іменників із аналізованим С3 виступають 5 префіксальних дієслів ДПЛ, на базі яких утворено 5 дериватів (2,8\%): викидайло (розм., заст.), випихач (розм.), витягальник, викатник (гірн.), виїздз «коні 3 екіпажем, упряжжю, збруєю». Наприклад: Се твої випихачі: $i$ тебе випхнуть з світа, а самі зостануться (Сл. Гр.).

На думку О.М. Хамідуліної, основою для формування агентивних найменувань виступає характер позначуваної ситуації, що супроводжує дію, у зв'язку 3 чим можна виокремити два типи похідних. 3 огляду на специфіку дієслівної дії деривати першого типу поділяються на підвиди - «виконавець-спеціаліст» i «виконавецьнеспеціаліст». При утворенні іменників другого типу, поява яких зумовлюється суміжними чинниками, актуалізується не сама дія, a, наприклад, модальна оцінка («може, уміє, любить»), часовий аспект («часто,завжди») дії тощо [16, с. 71-72]. Проаналізований матеріал дає змогу систематизувати агентивні найменування від префіксальних дієслів відповідно до класифікації О. М. Хамідуліної [13; 14]. Половину групи агентивів складають девербативи зі значенням «виконавець-неспеціаліст»: випихач (розм). «Смислова структура таких іменників будується за типовою схемою «той, хто діє» [16, с. 71]. Наприклад: випихач «той, хто випихає, виганяє». Іншу групу становлять девербативи зі значенням «виконавець-спеціаліст»: викидайло (розм., заст.), витягальник, викатник (гірн.). Як справедливо зазначає Н. М. Пославська, основою для побудови назв виконавців-спеціалістів виступають синтагми на зразок «робітник (фахівець, спеціаліст), здійснює (займається, виконує тощо) дію», пор.: викатник (гірн.) «робітник, який займається відкочуванням».

Отже, на відміну від непрефіксальних дієслів ДПЛ, які активно утворюють іменники на позначення виконавців дії, дієсловам ДПЛ 3 
префіксом ви- малохарактерне регулярне продукування nomina agentis.

Сам процес руху $є$ дуже складний. Він передбачає такі компоненти ситуації, як: 1) суб'єкт (той, хто виконує рух); 2) предикат переміщення; 3) вихідний пункт руху; 4) кінцевий пункт руху; 5) об'єкт; 6) адресат; 7) інструменталь (засіб руху). На думку дослідників, для дієслів руху обов'язковими є позиція суб'єкта і позиція спрямованості - обставина місця. Усі інші компоненти $є$ обов'язковими / факультативними залежно від структурнограматичних особливостей окремих дієслів, лексичного значення слова і комунікативних завдань висловлювання. У субстантивному блоці досліджуваних девербативів семантична позиція «місце дії» репрезентована 8 (4,5\%) похідними від 6 (7\%) твірних дієслів: ви́віз (діал.), вигін, вигул, виїзд2, вилаз, вилазка, вихід, виходок (діал.). Наприклад: I знову напливали n'янкі квітневі вечори, i Тоні зустрічав ї̈ біля виходу... (С. Кононенко); Вона якраз була у виходку, коли почула стрільбу, та так там і пересиділа до ночі... (М. Матіос); ...біля вчителевого будинку, від якого збігав крутий вивіз у Потоки, побачила Йосафата... (Р. Іваничук).

Слова, що становлять лексико-семантичний клас дієслів ДПЛ, означають механічне переміщення тіл відносно один одного або переміщення стосовно частин тіла. Механічний рух можуть здійснювати всі предмети об'єктивної дійсності. Одні 3 них здійснюють цей рух самостійно, активно (живі істоти), інші (неживі істоти) не здатні до активного руху.

Різноманітні форми механічного руху знаходять вираження в лексико-семантичному класі дієслів ДПЛ, зокрема і в значенні дієслів поступального руху, який вичленовується на основі ознаки «зміна положення у просторі», а також абстрактних категорійних ознак «характер руху», «спрямування руху», «середовище переміщення», «спосіб переміщення». Абстрактна категорійна сема «спосіб переміщення» конкретизується у значенні дієслів, які означають переміщення за допомогою транспортного засобу. Ця сема реалізується в дериватах із С3 «знаряддя», які виявлено в СП 3 (3,5\%) префіксальних дієслів: виїзд, викидач (спец.), виступецьь ${ }^{2}$ (розм.). Наприклад: У нього було два виїзди - кабріолет і тильбюрі (Н. Рибак).

Поодинокі деривати виявлено із С3 «об'єкт». Твірними для девербативів із аналізованим С3 виступають тільки каузативні дієслова ДПЛ: ви́віз, вигнанець, викидень, винос, виведенець (заст.). Наприклад: Душа бідного вигнанця терпіла багато під нестримним 
тягарем розлуки (І. Франко).

Отже, із 85 дієслів ДПЛ з префіксом ви- від 5 (5,8\%) зафіксовано деривати із семантичною позицією «об'єкт».

Ад'єктивна зона типової СП аналізованих лексем нараховує 35 (19,8\%) дериватів.

Ад'єктиви, мотивовані дієсловами ДПЛ, в українській мові складають незначний пласт лексики. Ад'єктивна зона СП дієслів ДПЛ представлена трьома семантичними позиціями: «ознака суб'єкта за дією», «ознака об’єкта за дією», «призначений для того, на що вказує твірне дієслово». Наявність у СП дієслів ДПЛ перших двох груп прикметників зумовлена в основному належністю твірних дієслів аналізованої ЛСГ до каузативних чи некаузативних підгруп. Це відбилося на значенні віддієслівних ад'єктивів: некаузативні дієслова ДПЛ, як правило, утворюють ад'єктиви із значенням «ознака суб'єкта», каузативні - «ознака об’єкта». До ад’єктивної зони дієслів ДПЛ зараховуємо й дієприкметники. Щодо їх статусу в системі частин мови й досі не існує єдиного погляду. Традиційним є визначення дієприкметника як дієслівної форми, яка поєднує в собі дієслівні морфологічні значення часу, виду i стану 3 прикметниковими формами роду, числа і відмінка. Ураховуючи те, що словотвірні характеристики дієприкметника подібні до словотвірних характеристик прикметника та що дуже часто дієприкметник піддається ад’єктивації, уважаємо доцільним розглядати дієприкметники як похідні ад’єктивної зони.

СП дієслів ДПЛ 3 префіксом ви- відзначаються двома дериватами, для яких характерне С3 «ознака суб'єкта за дією» реалізоване в СП 2 українських префіксальних дієслів ДПЛ: вибулий, вилізлий. Наприклад: ...всі навіки чи тимчасово вибулі з строю... (О. Гончар).

Похідні ад'єктиви із С3 «ознака об'єкта за дією» виявлено в кількості 24 (13,6\%) одиниці від 18 (21,1\%) префіксальних дієслів ДПЛ: вигнаний, виїжджений, викинений, виковзаний, викочений, винесений, вичовганий, виброджений, виведений, вивезений, виводжений, викинутий, викручений, виношений, виряджений, висковзаний, висунений, висунутий, виторений, витягнений, витягнутий, виходжений, виштовханий, виштовхнутий. Наприклад: ...ось тут список сімей, які завтра будуть вивезені... (Р. Іваничук); ...викотилася бебехата постать у довгополому кожусі, щзо й здалеку блищав вичовганою від вічного ночення чорнотою... (Р. Іваничук). 
Дериватів із С3 «призначений для того, на що вказує твірне дієслово» зафіксовано 6 у 5 СП дієслів ДПЛ з префіксом ви-: вивідний, виносний, висувний, витягальний, витягувальний, вихідний. Наприклад: Вихідні двері грюкнули, $i$ надвір вийшов хтось у довгій кереї (Ю. Смолич).

Вербальна зона типової СП аналізованих лексем репрезентована 58 (32,9\%) дериватами. Цю зону формують такі С3: «за допомогою дії, названої дієсловом, перемістити(ся) звідки-небудь кудись усіх чи багатьох», «виконуючи дію, переводити щось із стану об'єкта в стан суб'єкта», «однократність» й «у результаті виконання дії з'являтися, переміщатися на відкрите місце».

Похідних із С3 «за допомогою дії, названої дієсловом, перемістити(ся) звідки-небудь кудись усіх чи багатьох» серед досліджуваного матеріалу зафіксовано в кількості 27 одиниці (15,3\%), вони мотивовані 27 (31,7\%) твірними: повибігати, повибиратися, повиводити, повивозити, повиволікати, повиганяти / повигонити, повиїжджати / повиїзити, повикидати, повикочувати, повилазити / повилізати, повилітати, повиносити, повипадати, повипихати, повипливати, повиплигувати, повиповзати, повиринати, повискакувати, повистрибувати, повиступати, повисувати / повисовувати, повитаскувати, повитягати / повитягувати, повиходити, повиходжувати ${ }^{l}$, повиштовхувати. Наприклад: ...корови почули сигнал й повиходили з хащуів... (Р.Іваничук); ...на гостинецьь виїхало вантажне авто, зупинилося, 3 нього повискакувало четверо військових... (Р. Іваничук).

Семантична позиція «виконуючи дію, переводити щось із стану об' єкта в стан суб' єкта» актуалізована 25 (14,2\%) дериватами, які утворені від 13 (25,8\%) твірних дієслів: вимчатися, виноситися / виношуватися, видряпатися / видряпуватися, виводитися ${ }^{l}$, виволікатися, виганятися, вигонитися / вигнатися, вивозитися, виметнутися, виминатися, викидатися, висуватися / висовуватися, витаскуватися, виводитися ${ }^{2}$, вигребтися / вигрібатися, винестися / виноситися, витаскатися / витаскуватися, викотитися / викочуватися, виштовхатися, випхатися / випихатися, випроваджуватися, вирядитися / виряджатися, витягтися / витягатися, витягуватися, винестися / виноситися, висунутися / висуватися, висовуватися, викидатися / викинутися.

Деривати семантичної позиції «однократність» вказують на разовість, моментальність, недовготривалість процесу: вискокнути, вижбурнути, виштовхнути, вишпурнути. Наприклад: Йонька 
посунувся було [в хату] за тютюном, але Уляна виштовхнула його $в$ сіни (Г. Тютюнник).

Незначну кількість дериватів 3 (1,7\%) зафіксовано із С3 «у результаті виконання дії з'являтися, переміщатися на відкрите місце»: винестися / виноситися, висунутися / висуватися, висовуватися, викидатися / викинутися. Наприклад: Група вершників звернула 3 дороги і на скаку винеслась на круте узгір'я (І. Цюпа).

Адвербіальна зона типової СП аналізованих префіксальних лексем сформована С3 «адвербіалізація дії» і нараховує 4 (2,2\%) деривати - виплигом, вискоком, вистрибом, виступцем. Наприклад: Машина ковзається, виявляє тенденцію до руху вистрибом (Ю. Яновський).

Не зафіксовано похідних дериватів у СП 6 дієслів: вибасувати / вибасовувати, виблукати, виблудитися / виблуджуватися, виборсатися / виборсуватися, вибуксирувати, видряпатися / видряпуватися, що складає 7 \% від загальної кількості твірних.

\section{Умовні скорочення}

СУМ - Словник української мови. - К. : Наукова думка, 1970 - 1980. - Т. 1-11.

СУМГ - Словарь української мови / За ред. Б. Д. Грінченка. - К. : Наукова думка, 1996. - Т. 1-4.

ВТССУМ - Великий тлумачний словник сучасної української мови / Уклад. і головн. ред. В. Г. Бусел. - К.; Ірпінь : ВТГ «Перун», 2001. - 1440 с.

\section{Література}

1. Бачкур Р. Р. Структура словотвірних парадигм українських назв тварин та рослин : автореф. дис. ... канд. філол. наук / Р. Р. Бачкур. - Івано-Франківськ, 2004. - 20 с.

2. Бразаускене Е. М. Словообразовательный потенциал префиксальных глаголов : автореф. дис. ... канд. филол. наук / Е. М. Бразаускене. - М., 1991. - 22 с.

3. Валюх 3. О. Словотвірна парадигматика іменника в українській мові : [монографія] / 3. О. Валюх. - Київ-Полтава : АСМІ, 2005. - 356 с.

4. Грещук В.В.Український відприкметниковий словотвір / В.В.Грещук. Івано-Франківськ : Плай, 1995. - 206 с.

5. Гордеев Ю. М. Поле направленности (глаголы движения и их распространители) в современном русском языке : автореф. дис. ... канд. филол. наук / Ю. М. Гордеев. - Саратов, 1974. - 24 с.

6. Джочка I. Ф. Дериваційний потенціал дієслів конкретної фізичної дії 3 семантикою створення об'єкта : автореф. дис. ... канд. філол. наук / І. Ф. Джочка. Івано-Франківськ, 2003. -20 с.

7. Земская Е.А. О парадигматических отношениях в словообразовании / Е. А. Земская // Русский язык. Вопросы его истории и современного состояния. Виноградовские чтения 1-8. - М. : Наука, 1978. - С. 63-77.

8. Кіндей Л. Специфіка локативної семантики префікса ви- у дієслівних похідних / Леся Кіндей // Наукові записки. - Вип. 35. - Серія : Філологічні науки (мовознавство). - Кіровоград : РВЦ КДПУ ім. В. Винниченка, 2001. - С. 156-164. 
9. Ленець К. В. Подвійно префіксовані дієслова 3 префіксом по- / К. В. Ленець // Мовознавство. - 1979. - № 3. - С. 26-29.

10. Лесюк М. П. Формування семантики віддієслівних іменників / М. П. Лесюк // Українське мовознавство. - К. : Вища школа, 1987. - Вип. 14. - С. 74-80.

11. Микитин О. Д. Структурно-семантична типологія словотвірних парадигм іменників сучасної української мови : автореф. дис. ... канд. філол. наук / О. Д. Микитин. - Івано-Франківськ, 1998. - 20 с.

12. Пославська Н. М. Структура і семантика словотвірних парадигм дієслів із семою руйнування об'єкта : автореф. дис. ... канд. філол. наук / Н. М. Пославська. Івано-Франківськ, 2006. - 20 с.

13. Сегін Л. В. Структурно-семантична типологія словотвірних парадигм дієслів динамічної просторової локалізованості в українській і польській мовах : автореф. дис. ... канд. філол. наук / Л. В. Сегін. - Донецьк, 2003. - 20 с.

14. Сегін Л. В. Дериваційний потенціал дієслів динамічної просторової локалізованості з префіксом ПІД- в українській мові / Л. В. Сегін // Семантика мови і тексту : Матеріали IX Міжнародної наукової конференції. - Івано-Франківськ, 2012. C. 545-548.

15. Словотвір сучасної української літературної мови. - К. : Наукова думка, 1979. $408 \mathrm{c}$.

16. Хамидуллина А. М. Отглагольные имена деятеля в ономасиологическом аспекте / А. М. Хамидуллина // Исследования по семантике : Лексическая и синтаксическая семантика. - Уфа : Изд-во Башкир. ун-та, 1981. - С. 67-73.

17. Хамидуллина А. М. Словообразовательные парадигмы глаголов движения (внутриглагольная деривация 2 такта порождения) / А. М. Хамидуллина // Исследования по семантике : Межвуз. научн. сб. - Уфа : Изд-во Башкир. ун-та, 1975. Вып. 1. - С. 93-107.

18. Чиканцева Т. В. Словообразовательные парадигмы непроизводных глаголов современного русского языка : автореф. дис. ... канд. филол. наук / Т. В. Чиканцева. Л., 1984. -22 с.

19. Янценецкая М. Н. Семантические вопросы словообразования : Производящее слово / М. Н. Янценецкая. - Томск : Изд-во Томск. ун-та, 1991. - 271 с. 